\title{
Cognition in comparative and strategic management research
}

\section{Jurgen Poesche}

Department of Industrial Engineering and Management,

Aalto University,

P.O. Box 15500, 00076 Aalto, Finland

Email: jurgen.poesche@aalto.fi

\begin{abstract}
The objective of this paper is to synthesise a view of cognition in the context of comparative and strategic management research. In this paper, the view that there is a firm-specific cognition is rejected. Cognition is seen as a product of the culture of society. Firms may have a resemblance of cognition, but this is the result of opportunistic behaviour by and selection of employees. This resemblance of cognition is potentially destructive for a firm because of reduced cognitive pluralism. In the face of crisis and failure, the detrimental effects of reduced cognitive pluralism are exacerbated by an escalation of commitment, and an implicit sameness or separateness assumption. The problems associated with this have been manageable because of the occidental enjoyed economic, legal and technological global dominance. In an increasingly pluralistic world, research into comparative and strategic management needs to pay attention to cognitive diversity. The strengthening of non-occidental societies - among them China, India, Indigenous American nations and in Sub-Saharan Africa - complicates cognition-related research into comparative and strategic management.
\end{abstract}

Keywords: cognition; cognitive concordance; culture; opportunistic behaviour; pluralism; strategy.

Reference to this paper should be made as follows: Poesche, J. (2019) 'Cognition in comparative and strategic management research', Int. J. Comparative Management, Vol. 2, Nos. 3/4, pp.229-246.

Biographical notes: Jurgen Poesche has worked for a total of 18 years in academia, consulting and industry. He has earned three doctoral degrees, one each in Business, Engineering and Law. His current research interests include legal pluralism and scientific pluralism with a particular focus on indigenous nations.

\section{Introduction}

Much of the current strategic management literature on cognition is predicated on the implicit assumption that firms face the same cognitive environment (implicit sameness assumption), or at the very least that firms can be considered cognitively separate from their cognitive environment (implicit separateness assumption). For reasons assessed in this paper, both of these implicit assumptions are factually wrong. The objective of this 
paper is to synthetise a view of cognition in the context of comparative and strategic management research.

Whereas implicit assumptions are not clearly expressed, it is necessary to engage in textual analysis to find them in the silences. The implicit sameness or separateness assumption can be found in, e.g., Barr et al. (1992), Agarwal and Helfat (2009), Salvato and Vassolo (2017), Dane (2018) and Raffaelli et al. (2019). Cognition is important for firms, because cognitive blind spots impede the recognition of the need for change as has been argued by, e.g., Tripsas and Gavetti (2000) and Aggarwal et al. (2017). Additionally, capabilities have a cognitive foundation (Gavetti, 2005).

A change in cognition has been considered within the confines of firms with changes to cognition at the societal level being treated as externalities (Christianson, 2019) - this line of argument is predicated on the implicit separateness assumption. A focus on communities of practice does not necessarily solve the issue of the implicit sameness or separateness assumption as the discussion in Beane (2019) shows. The implicit sameness or separateness assumption can also be discerned in, e.g., Granero et al. (2017) and Leslie et al. (2019): They interpret cognitive pluralism in terms of job-related (functional) and non-job-related (age) factors.

To spark beneficial outcomes for a firm, the situated cognition view of multiculturalism - discussed by, e.g., Hong et al. (2000), Elsbach et al. (2005) and Vora et al. (2018) - would require that any cognitive compartmentalisation is kept at a minimum. This, in turn, would require the rejection to any implicit sameness or separateness assumption. The argument that exposure to multiple cultures favours multiculturalism (Lücke et al., 2014) is effectively contingent on openness vis-à-vis cognitive pluralism found in society. Openness to cognitive pluralism is not without its challenges: The discussion of categorisation in Zunino et al. (2019) suggests that multiculturalism may result in dissonance.

It certainly can be argued that there are individual differences in cognition, e.g., Teece (2007) and Helfat and Peteraf (2015), but this does not falsify the view that cognition is primarily a societal phenomenon. Moreover, dual processing theories of cognition (Peterson and Barreto, 2018) - individual and society - fail to recognise that firms may attempt to impose a third processing level.

When firms act in accordance with an implicit sameness or separateness assumption, firms may become blind to opportunities and threats. The concept of escalation of commitment showcases such blindness: the insight that an escalation of commitment results in ignoring the unfavourable effects of the associated decision making (Wong and Kwong, 2018) may cause firms to exclude opportunities and threats from consideration when these opportunities and threats are outside of firms' cognitive boundaries. If firms' escalation of commitment fails to bring success, the result may encompass cognitive paranoia. Trait mindfulness has been found to offer a defence against paranoid cognition (Thoroughgood et al., 2019), but it must be asked whether trait mindfulness also creates a cognitive obstacle to recognising cognitive pluralism between societies.

The layers of cognition identified in cognitive science may have led to misconceptions about cognition in the comparative and strategic management literature. There is an inborn core cognition that is valid throughout humanity (Strickland, 2017) exemplified by a fear of heights. More complex cognition is learned, and this learning occurs within society. As the research of, e.g., Wade and Kidd (2018) demonstrate, learning gives rise to very different cognitions from society to society - or from societal culture to societal culture. 
In this paper, cognition is viewed a product of culture where culture is considered to exist at the societal level (D'Andrade, 1981; Oyserman, 2011; Muggleton and Banissy, 2014). The three approaches - social perception, information processing and social motivation - in social cognition identified by Kiesler and Sproull (1982) are all impacted by society. Cultural differences result in different cognitions as demonstrated in the work of, e.g., Hofstede (2010) and Ronen and Shenkar (2013). A study by Putranto et al. (2018) seems to suggest that a deep embed in the occidental cognition and culture is detrimental to accommodating cultural differences, and thus cognitive pluralism. At the same time, the finding that social interaction amplifies cognitive bias (Fay et al., 2018) is thought provoking.

The insight that the same measures that have made a system predictable and safe may actually limit cognition (Oliver et al., 2017) is interesting when escalated to the level of societies, because the success of the occident may actually be its undoing. This insight is also interesting at the firm level, because predictability and safety may be associated with an escalation of commitment particularly in the context of mounting challenges. Firms' decision making has been seen as a situational phenomenon mingling action and cognition (Journé and Raulet-Croset, 2012).

Considering the growing importance of East Asia, it is notable that there are fundamental differences between the occident (societies defined by the European culture) and East Asia as shown in the work of, e.g., Norenzayan et al. (2002), Masuda and Nisbett (2006) and Ueda et al. (2017). The emergence of Sub-Saharan Africa from coloniality, and the adoption of legal pluralism in several Latin American states will increasingly raise the issue of societal cognition versus coloniality.

A caveat is in place: cognitive differences between societies may be used to defend racism (Menéndez, 2018) - and extant coloniality - if one society considers its cognition to be superior vis-à-vis the others. Concomitantly, denying cognitive differences between societies contributes to the homogenisation which in combination with asymmetrical societal power structures may result in cognitive discrimination and even extinction.

Do differences in societally-defined cognitions matter for firms and research outside of the ethical and legal realms? As long as multinational firms were from societies with similar cognitions - i.e., the occident in the 19th and 20th centuries - the implications of cognitive differences were limited: Monsanto (USA) competed with Syngenta (Switzerland), Linde (Germany) competed with Air Liquide (France), and so on. In the 21 st century, the competition is increasingly between firms from societies with dissimilar cognitions: Bayer (Germany) competes with ChemChina (China), Bombardier (Canada) competes with CRRC (China), and so on.

Apart from this interfirm aspect, there is the intrafirm aspect. Firms need to decide whether to attempt to impose a firm-wide cognition across all societies, or to embrace intra-firm cognitive pluralism. E.g., ChemChina needs to decide on the role of Sino cognition in its Syngenta subsidiary in Switzerland, and BASF needs to determine the degree of occidental cognition in its production plant in Lagos.

This paper is divided into three sections. In the first section, cognition is considered through the lens of the comparative and strategic management literature. This section is divided into three subsections dealing with the location of cognition, cognition and institutions, and cognitive pluralism. In the second section, cognition is considered through the lens of the cognitive science literature. This section is divided into three subsections dealing with cognitive science and culture, cognitive science and problem 
solving, and cognitive science and emotions. In the third section, the findings in the previous two sections are discussed.

\section{Methodology}

Methodology is related to the logic and rationale which buttress the techniques used to accumulate and collect data for a study (Roberts, 2014). The logic and rationale buttressing this conceptual paper is critical realism - a combination of critical naturalism and transcendental realism founded on the work of Bhaskar (2008).

The scholarship of, e.g., Hockey (2010) demonstrates that occidental methodologies can be discriminatory against non-occidental cognitions. From the standpoint of cognition-related research, the work of, e.g., Hwang (2015) showed that cultural differences between the various cultural spheres have not been taken sufficiently into account in psychological research in addition to the conclusion that critical realism offers a path forward is of interest. One way to overcome this discrimination is to adopt cognitive pluralism. Cognitive justice is associated with cognitive pluralism (Burt et al., 2018).

A necessary step to address the injustice and tyranny associated with implicit practices relating to methodology is to render them explicit (Harré, 2009). Addressing the cognitive injustice and tyranny in methodology is made challenging by the erroneous belief that the currently dominant methodologies would not contain an occidental bias in spite of their occidental roots.

The term critical in critical realism has been used in the connotations of:

1 epistemological realism

2 emancipatory in intent (Fay, 1990).

Critical realism is epistemologically realistic by recognising that there are non-occidental cognitions, and therefore non-occidental epistemologies and methodologies; and that these non-occidental cognitions, epistemologies and methodologies are equal to their occidental counterparts. Critical realism maintains that "the world is 'layered' into different layers of reality" and that knowledge is fallible "insofar that the complexity of the world implies that our knowledge of it might be wrong or misleading and so the job of social investigators is to keep searching for knowledge about causal mechanisms in different research contexts" [Roberts, (2014), p.2].

In discussing Roy Bhaskar's later dialectical work, Roberts (2014) notes that abstract social structures do obtain their historical identity from the dialectical interactions between history and social structures instead of being solely parts of the historical flow. Ultimately, this means that the occidental cognition - and hence also the occidental logic and rationale - cannot be separated from occidental history. It has been noted that for "advocates of critical realism the plurality of the sciences is necessary because of the irreducibly stratified character of the mechanisms at work in the real world" [Pratten, (2013), p.255]. 


\section{Cognition in the comparative and strategic management literature}

This paper rejects the notion that there is a firm-level cognition separate from society-level cognition. It does recognise that there is a bandwidth of legitimate cognition in society, and that there may be an appearance of a firm-level cognition as the result of hiring practices favouring candidates representing one part of the bandwidth. Another factor that may give the appearance of the existence of a firm-level cognition is that individuals act opportunistically in the sense that they behave according to the wishes of their managers without subscribing to the cognition espoused by them.

\subsection{Location of cognition}

Some of the comparative and strategic management literature, e.g., Voyer (1994), has been clear that cognition is found at the level of individuals in firms. Another way to look at cognition has been to consider that different professional groups have their own cognitions, e.g., Boland and Tenkasi (1995). More broadly, it has been argued that groups of individuals develop strategies (Porac et al., 1989; Gavetti and Warglien, 2015) and ways to interpret the environment (Dutton and Dukerich, 1991), but deducing from this that there is a group-level cognition separate from society-level cognition is troubling.

Particularly in the newer comparative and strategic management literature it has been at least implicitly assumed that:

1 firms have a cognition separate from society's

2 firms can change their cognition, e.g., Barr et al. (1992), Mezias et al. (2001), Agarwal and Helfat (2009), Salvato and Vassolo (2017), Grewatsch and Kleindienst (2017), Laamanen et al. (2017), Liang et al. (2018) and Christianson (2019).

A postulated mechanism for the emergence of a firm-level cognition would be the shared experience in working for the same firm - the experience factor has been assessed by Maitland and Sammartino (2015). Subsuming the emergence of new cognition from experience is a stretch, because - as is discussed in more detail below - cognition is rooted in culture, and experience is not necessarily the same as culture.

Experience is not necessarily the same as learning, and when a nexus between cognition and learning is considered it needs to be recognised that learning happens in society and in the culture of the society in question as has been shown in, e.g., Wade and Kidd (2018). As Klein (1973) has noted: culture plays a decisive role in the development of cognition.

When considering the concepts of cognition and culture, a caveat is in place. Pinder and Bourgeois (1982) have warned against the borrowing from other academic disciplines. Culture has been borrowed from anthropology (Smircich, 1983), and cognition from psychology. Instead of giving cognition and culture different meanings in the comparative and strategic management literature, it is warranted to respect their original definitions in anthropology and psychology. E.g., there certainly was an Aztec culture and a Roman culture, but there was no pochteca culture and a Marcus Licinius Crassus culture in anthropology. Similarly, every human has only one brain. Thus, there is not a separate brain for psychology and strategic management. 
Gavetti and Levinthal (2000) have argued that changing cognition is a way to adapt to the environment, but this assumes that cognition can be changed. Cognition has been described as fairly stable, e.g., Irwin et al. (2017), but also an opposite view has been expressed, e.g., Gioia et al. (2010). It is thus unrealistic to assume that individuals change their cognition. It is more realistic to assume that an individual's cognition remains stable, and in the face of pressure the individual responds by opportunistic behaviour. A firm can steer the cognition found in a firm by choosing employees who share the firm's desired cognition, but this is limited by the cognitive bandwidth defined by society. Furthermore, it is questionable whether a firm can separate between cognition and opportunistic behaviour.

Historically, the emphasis in the strategic management literature has been on reducing cognitive uncertainty, but this has been changing (Michel, 2007). The examples used by Michel (2007) are of limited cognitive uncertainty, because all of them are from the occident. Moreover, the occidental dominance in the formulation and interpretation of international public law has led to a regulatory convergence (Negro and Longhofer, 2018).

The re-emergence of societies with very different cognitions as major economic and technological players is conducive to increasing cognitive uncertainty. Instead of reducing cognitive uncertainty, attempts to analyse and describe non-occidental cognitions and cultures using the occidental cognition and culture are prone to result in an escalation of commitment, and ultimately erect barriers of incomprehension and thus delay necessary action by firms.

Limiting cognition to the societal level narrows the perspective - and narrowing has been criticised in the comparative and strategic management literature by, e.g., Sullivan (1998) - because other sources for cognition than society are not recognised. At the same time, it broadens the perspective by stressing the pluralism emanating from cognitive and cultural differences between societies.

Paradigmatic rigidity has been found to be an impediment to breakthrough in research and development (Chai, 2017). Although this finding is contextualised to barriers between research projects and scientific disciplines, assuming that the occidental cognition and culture dominates the global economy and technology introduces paradigmatic rigidity also into comparative and strategic management research, and strategic management. Opening research to encompass non-occidental cognitions as equal to the occidental cognition is a way to reduce rigidity.

Simon (1987) has been associated cognition with poor decision making. This does not need to be the case. It is necessary to recognise the cultural and cognitive limitations to proactively identify and eliminate poor decisions as the result of cognitive blind spots, and rigidity.

\subsection{Cognition and institutions}

The challenge of barriers of incomprehension extends into the realm of institutions. Culture forms the foundation for institutions which in turn impact human behaviour and human cognition. Societies are characterised by a large number of institutions, be it social institutions like ethics and morality, or legal institutions like legal principles reaching back centuries - considering institutions as expressions of ethics, law and morals can be reconciled with Galen's use of the term in Institutes in AD 161. 
The view that cognition is a societal phenomenon with some individual variance can be seen in the context of the argument that institutions are not limited to a background role and that institutions directly influence strategic decision making (Meyer et al., 2009; Gao et al., 2017), because institutions tend to be the result of lengthy historical developments.

Power is often related to institutions. Krackhardt's (1990) argument that cognition is used in the assessment of a (power) network. The challenge associated with cognitive barriers of incomprehension is that an individual does not understand the (power) network founded on another cognition. E.g., the factual distribution of power in occidental and Chinese state-owned firms may be different because of cognitive differences.

\subsection{Cognitive pluralism}

Although (societal) cross-cultural differences have received some attention in comparative and strategic management research, e.g., Franke et al. (1991), Steers et al. (2012) and Li et al. (2017), the research has been hampered by its focus on the occident, and hence the occidental cognition and culture. As long as there was an occidental economic, legal and technological global dominance, the implications of this bias for comparative and strategic management research were limited. With the re-emergence of particularly China and India with their cognitions and cultures as major economic and technological powers in addition to changes in Africa and Latin America, non-occidental cognitions and cultures cannot be ignored any longer.

Again a caveat is in place: If firm-level cognition is considered independent of society-level cognition, then the assumption of a similarity of the cognition in firms from different cultures seems viable. This may give rise to significant errors not only in comparative and strategic management research but also in strategic management, because it cannot be assumed that cognitions and cultures in firms like ChemChina and Sinopharm on the one hand are the same as in firms like BASF and Roche on the other hand - this speaks to the inadequacy of the implicit sameness or separateness assumption.

The cognitive and cultural differences between ChemChina and Sinopharm on the one hand, and BASF and Roche on the other hand would seem to be truisms. It is therefore surprising to consider the reference lists of the highest ranked journals in strategic management. References to works - irrespective of the ethnic origin of the authors - explaining the views of, e.g., Confucianism, Hinduism, Mexicayotl and the Yoruba religion on strategic management: Almost non-existent in the top-rated strategic management journals.

The scarcity of non-occidental views is troubling in two ways. First, in a hierarchical cognitive system religion-related moral occupies the apex (Strohminger and Nichols, 2014). Second, cognitive differences have been observed in cross-cultural studies, e.g., Boyer and Ramble (2001), Hong and Chiu (2001), Norenzayan et al. (2002), Fay et al. (2018) and Willard and McNamara (2019). Thus, in the strategic management literature attempts are made to analyse and describe the phenomenon of strategic management in non-occidental firms or in non-occidental societies by the expedient of occidental culture and cognition. It is doubtful that this can objectively succeed, and this creates the threat of a cognitive blind spot in strategic management practice and research. 
It is unrealistic to expect that Africans, Chinese, Indians, Indigenous Americans, occidentals and others change their respective cognition. What may be more realistic is that individuals from societies with different cognitions are better equipped to thrive in a changed environment, e.g., an environment characterised by the re-emergence of particularly China and India with their cultures and cognitions. This is made more important in view of the observed norm tightness in different societies. Gelfand et al. (2011) and Shin et al. (2017) have argued that norm tightness has to be considered in addition to cultural distance. East and South Asian societies have some of the highest tightness scores (Gelfand et al., 2011). Hence, it cannot be assumed that East and South Asian societies - and individuals from these societies - will adopt the occidental cognition and culture.

\section{Cognition in cognitive science}

In the cognitive science literature, societal culture, emotions and problem solving have received significant attention. Therefore, the cognitive science literature raises doubts about the existence and even the possibility of firm-specific cognitions.

\subsection{Cognitive science and culture}

A challenge in the use of the term cognition is that the term culture is not defined unequivocally in social sciences. This void is problematic in the research of cognition, because culture impacts cognition and perception (D'Andrade, 1981; Oyserman, 2011; Muggleton and Banissy, 2014). In this paper, culture is understood to refer to culture at the societal level. Whereas culture is considered to be the human culture that has developing over 50 millennia in cognitive science (D'Andrade, 1981), culture is considered particularly in newer business literature to be firm-specific and relatively easily changeable. In this paper, cognition is considered relatively stable over time. This does not mean that there would not be change, or that a cognition in a society would be immune against external influences.

An example of imported cognition-related processes is the strength of dialectic thinking in China as a result of Marxist teaching (Zhang et al., 2015), but this has coincided with deep changes in the Chinese society since 1949. Simultaneously, it needs to be kept in mind that traditional Chinese thinking - and thus the associated cognition are influential in today's China as shown in, e.g., Marchal (2017). The rise of legal pluralism in Latin America (Galván, 1997; Andrade, 2007) also demonstrates the stability of cognitions and cultures over time even against the backdrop of discrimination and cultural genocide, in this case Indigenous American nations' cognitions and cultures.

Fundamental cognition-related differences have been found between different human cultures. Because the timely identification of discontinuous change and related exploration are of great importance in strategic management, the interaction of cognition and exploration warrants some attention. In a cross-cultural study, Wade and Kidd (2018) found that Indigenous American Tsimane school-aged children exhibit a greater propensity for exploration than their US counterparts. Moreover, Tsimane school-aged children are less influenced by age-based authority represented by, e.g., teachers (Wade and Kidd, 2018). These findings raise the prospect that the occidental education and upbringing suppress exploration outside of the confines of the current occidental culture 
and episteme. For strategic management, such a suppression would mean the prevalence of an escalation of commitment.

Human cognition has been found to be strongly impacted by the use of socially shared symbols (Fay et al., 2018). In different societies, what is socially shared may differ significantly. As noted, different symbols signify different cognitions. For strategic management, the interrelationship between cognition and socially shared symbols raises the issue of cognitive bias being introduced by differences in shared symbols - a bias that could adversely affect the identification of opportunities and threats.

Societies have been divided into different groups based on their cognitions and cultures, e.g., Hofstede (2010) and Ronen and Shenkar (2013). Figure 1 shows that different cognitions intersect, but there are areas of difference. The intersection can be interpreted to be the inborn core cognition postulated in Strickland (2017). Cognitive differences result in differences in strategic decision making, e.g., Mitchell et al. (2000).

Figure 1 Intersecting cognitions

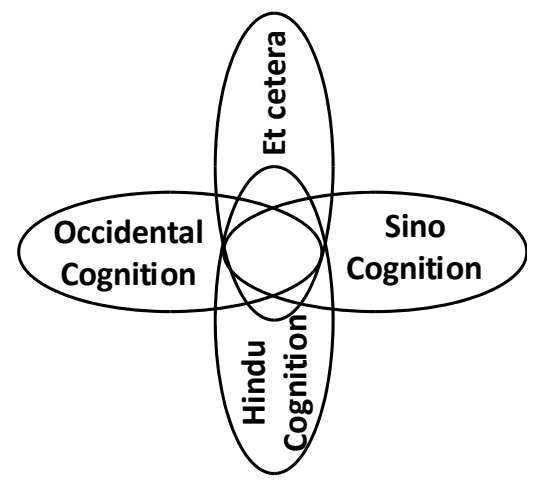

Although it has been argued that collectivist and individualistic approaches can be found and activated in different cultures (Oyserman, 2011), this does not translate into the existence of a globally uniform cognition and culture. There are differences in degrees within and particularly between societies. As there are variations in human behaviour in society, there is a bandwidth of acceptable behaviour in society. Which behaviours fall within the acceptable bandwidth varies from society to society as defined by their respective culture. Similarly, there is a bandwidth of acceptable cognitions in each culture.

In many instances, differences in cognitions go to the very foundations of the way the environment is observed. Chinese and occidental cognitions epitomise these fundamental differences by attributing different roles to the five human senses (Huanan, 2017). Language is another source of differences. The comprehension of the world is evident in language and encoded differently in different cultures (Núñez and Cornejo, 2012).

The combination of language and society impacts social interactions (Tenzer et al., 2014; Volk et al., 2014; Jalonen et al., 2018), but the business literature has not addressed the strategic management-related implications of there being multiple languages satisfactorily, e.g., the first language of society A is X and firm B imposes language $\mathrm{Y}$ in intrafirm communications in society A. The work in Wang et al. (2019) suggests that linguistic skills may not be sufficient as long as deeper properties associated with a society are not present. Considering the cognitive nexus between a culture and the 
language associated with it, it is doubtful that the imposition of one language allows for a pluralistic mindset - a concept for taking advantage of cultural pluralism proposed in van Knippenberg et al. (2013).

The differences between cultures are fundamental. E.g., anatomical and neural differences founded on cultural background have been found in math-related processing (Tcheang, 2014). The resulting cognitive differences are hence so fundamental that changing an individual's cognition is unlikely. The issue then becomes how an individual deals with a situation that is incongruent with the individual's cognition. The answer is not a change in cognition, but the answer is opportunistic behaviour. It is not sufficient to consider a CEO's cognition as done by, e.g., Kaplan (2008). From the standpoint of strategic management the issue arises where to place a firm on the cognitive concordance - opportunistic behaviour continuum, see Figure 2.

Figure 2 Cognitive concordance - opportunistic behaviour continuum

\section{Opportunistic Behaviour}

\section{Cognitive Concordance}

\subsection{Cognitive science and problem solving}

Strategic management may involve complex problem solving as do, e.g., invention and innovation. In cognitive science, it has been found that the strategies used in complex problem solving vary from society to society. This finding renders any implicit sameness or separateness assumption problematic in comparative and strategic management practice and research.

Complex problem solving depends not only on the specific demands of the situation, but particularly on country-specific - or society-specific - problem-solving strategies (Güss et al., 2010). Whereas an analytical mode emphasising isolated units is used in the occident, a holistic mode emphasising relationships is used in East Asia (Norenzayan et al., 2002; Masuda and Nisbett, 2006; Ueda et al., 2017).

Significant differences between the occident and East Asia have been observed in the processing of visual input (Ueda et al., 2017). Whereas occidentals use rule-based approaches, East Asians use intuitive approaches - neither guarantees accuracy in reasoning (Norenzayan et al., 2002). Significant cultural differences in narrative construction have been observed between the occident and East Asia (Senzaki et al., 2014). In agreeing that cultural differences exist, Umla-Runge et al. (2014) note that differences in encoding lead to salient objects being preferentially processed in scenes, but contextual information is more taken into account in East Asia.

\subsection{Cognitive science and emotions}

The interrelationship of cognition and emotions has been raised in the business literature, e.g., Barsade (2002), van Hoorebeke (2008), Vuori and Huy (2016), Giorgi (2017) and Raffaelli et al. (2019). One form of emotion is nationalism (Lubinski and Wadhwani, 2019), but it has also been claimed that emotions are firm-dependent (Petriglieri et al., 2019). Nationalism is undoubtedly a society-related phenomenon, but firms are not 
societies. In some instances, a firm may be a (shared) symbol of a particular society, e.g., ChemChina may be considered a symbol of China, and Gruma a symbol of Mexico. In such cases, firms can be interpreted as placeholders for the actual object of emotions society.

What remains ultimately unresolved in the emotions-related literature is the roots of the emotions impacting cognition, i.e., are these emotions rooted in cerebral functions found in all humans, or are these emotions culturally dependent? In the case of societal culture-dependency, how do emotions impact cognition in the context of strategic management? Particularly strong emotions may give rise to an escalation of commitment, and hence facilitate the occurrence of cognitive blindfolds which adversely affect strategic management.

\section{Discussion}

The assessment performed in this paper suggests a view of cognition in strategic management that is both narrower and wider as found in much of the contemporary comparative and strategic management literature. It is narrower by rejecting the notion that there would be a firm-level cognition separate from the society-level cognition. There may be the inaccurate perception of a separate firm-level cognition in two cases. First, individual employees engage in opportunistic behaviour congruent with the firm management's expectations even if this means that their cognition is violated. Second, individuals' cognitions are not identical in a society but within an acceptable bandwidth. A firm is thus able to hire employees from a particular segment of the bandwidth. In both cases, cognition is defined by society and its culture.

The view of cognition in this paper is wider, because it recognises that there is a pluralism of cognitions as the result of differences between societies. The re-emergence of non-occidental societies - most notably China and India in the business realm, and Indigenous American nations as a result of the adoption of legal pluralism in several Latin American jurisdictions - means that additional cognitions are gaining importance. Because of differences in society-level cognitions, it is reasonable to expect that firms like ChemChina and Sinopharm on the one hand exhibit different cognitions than BASF and Roche on the other hand. The cognitive differences between societies are operationalised in firms by the cognitions of individual employees which are defined by society.

Empirically, it is certainly possible to find that ChemChina, Sinopharm, BASF and Roche are cognitively similar. The issue here is that empirical research has a tendency to find what is searched for by the researchers. This phenomenon is worsened by the desire of some non-occidental researchers to be more occidental than most occidentals, because the occident is associated with power, success, technological excellence and wealth. Therefore, non-occidental researchers do not always speak with a non-occidental voice but a particularly occidental voice - particularly if they feel that this is necessary for publishing in occidental journals. Empirical methods can thus be misleading in comparative and strategic management research.

Biases in favour of one societal cognition are problematic from the standpoint of practice and research. If this one societal cognition is under threat, then an escalation of commitment vis-à-vis this societal cognition cannot be ruled out. Via individuals 
employed by firms, such an escalation of commitment spreads into firms and their strategic management.

The strategic implications of an escalation of commitment encompass a clinging to and radicalisation of concepts congruent with the societal cognition in question even in the face of mounting evidence of the societal cognition's failure. Two examples hereof are warranted. First, the challenge of drug resistant pathogens (Gallant et al., 2017) is forcing the occidental pharmaceutical industry to fundamentally rethink the limits of occidental medicinal and pharmaceutical chemistry (Cheng, 2011; Sen and Chakraborty, 2017). An escalation of commitment by the occidental pharmaceutical industry to chemistry founded on the occidental cognition would very likely have lethal consequences.

Second, it is increasingly obvious that the occidental cognition has failed to fend off climate change caused by humans. An increase of greenhouse gas concentrations in Earth's atmosphere followed the emergence of agriculture 8,000 years ago (Ruddiman, 2003), but the concentration of carbon dioxide in the atmosphere soared as a result of the dynamics put into motion by the First Industrial Revolution (Henriques and Borowiecki, 2017). Soaring greenhouse gas emissions and the associated rise in carbon dioxide concentration in the atmosphere were a result of the ultimately worldwide adoption of technology of occidental extraction. An escalation of commitment vis-à-vis the occidental cognition contains the danger that solutions to a crisis caused by the occidental cognition is paradoxically sought within the confines of the same occidental cognition. Arguably, it would be more logical to seek solutions elsewhere.

A search for solutions for the challenges posed by drug resistant pathogens and climate change is hampered by implicit sameness and separateness assumptions, if these effectively reinforce the search for solutions within the confines of the occidental cognition. In a crisis, an escalation of commitment on the one hand, and implicit sameness and separateness assumptions are prone to be mutually reinforcing thus impeding the identification and development of effective and efficient solutions.

The view of cognition in comparative and strategic management presented in this paper has two major implications for comparative and strategic management research, and the strategic management practice. First, it makes clear that attempts at creating a firm-level cognition cannot succeed, because there is no firm-level cognition separate from society-level cognition. Attempts at creating firm-level cognitions are inherently destructive, because they result in opportunistic behaviour and/or extreme cognitive narrowness. Thus: Cynicism is encouraged, and strategic management is detrimentally affected.

Second, it is necessary to embrace cognitive pluralism between societies in order to broaden the cognitive foundation of invention and innovation. This entails rejecting the view that there is one dominant cognition and that all other cognitions should be managed in such a way as to impede challenges to the dominant cognition.

\section{Conclusions}

It has been argued in this paper that a firm-specific cognition does not exist. There may exist something that resembles a firm-specific cognition because of opportunistic behaviour and employee selection, but a resemblance is different from reality. For comparative and strategic management research, this has significant implications. 
If a firm-specific cognition existed, then it would significantly contribute to cohesion within the firm. The outcome of the rejection of a firm-specific cognition presented in this paper is that a resemblance of a firm-specific cognition is destructive. On the one hand, opportunistic behaviour leads to lip-service and cynicism that is unlikely to improve cohesion and performance. On the other hand, personnel selection based on cognitive concordance is prone to reduce cognitive plurality and thus the cognitive foundation of innovation - the lack of cognitive plurality (especially when paired with the implicit sameness or separateness assumption) increases the likelihood of an escalation of commitment when a crisis takes hold.

Any detrimental strategic repercussions of a lack of cognitive plurality are exacerbated by a contemporaneous implicit sameness or separateness assumption. It is thus important to critically consider the strategic implications and source of the resemblance of a firm-specific cognition in empirical and theoretical work.

As long as the occident has enjoyed economic, legal and technological global dominance, the research challenges resulting from cognitive plurality have been limited. The bandwidth of occidental cognition has meant that firms have not been able to stray far away from the cognition in society-at-large. This has effectively limited opportunistic behaviour. The strengthening of non-occidental societies - e.g., China and India - with cultures significantly differing from the occidental culture means that there is an increase in cognitive pluralism. This increase in the cognitive pluralism increases the likelihood of incompatible cognitions colliding and thus the emergence of opportunistic behaviour. Such collisions have received very little attention in the literature in spite of their growing importance. This opens significant research opportunities in an increasingly multipolar and cognitively pluralistic world.

Of particular concern is the phenomenon in research that researchers find what they are looking for. If occidental concepts founded on the occidental cognition are used to analyse non-occidental firms, it is almost certain that it is found that non-occidental firms are similar with occidental firms. Evidence to the contrary is ignored. As a result, the resulting empirical work and theory building is not founded on all aspects of the phenomenon and thus it is fundamentally flawed.

The argument of the non-existence of a firm-specific cognition gives new impulses to empirical research and theory building in comparative and strategic management. The increasing economic, legal and technological significance of cognitive pluralism in the world of business makes it more important to consider the foundations of cognition.

\section{References}

Agarwal, R. and Helfat, C.E. (2009) 'Strategic renewal of organizations', Organization Science, Vol. 20, No. 2, pp.281-293.

Aggarwal, V.A., Posen, H.E. and Workiewicz, M. (2017) 'Adaptive capacity to technological change: a microfoundational approach', Strategic Management Journal, Vol. 38, No. 6, pp.1212-1231.

Andrade, O.A. (2007) 'Los sistemas jurídicos indígenas frente al derecho estatal en México: Una defensa del pluralismo jurídico', Boletín Mexicano de Derecho Comparado, No. 118, pp.9-26.

Barr, P.S., Stimpert, J.L. and Huff, A.S. (1992) 'Cognitive change, strategic action, and organizational renewal', Strategic Management Journal, Vol. 13, No. S1, pp.15-36.

Barsade, S.G. (2002) 'The ripple effect: emotional contagion and its influence on group behavior', Administrative Science Quarterly, Vol. 47, No. 4, pp.644-675. 
Beane, M. (2019) 'Shadow learning: building robotic surgical skill when approved means fail', Administrative Science Quarterly, Vol. 64, No. 1, pp.87-123.

Bhaskar, R. (2008) Dialectic: The Pulse of Freedom, Routledge, London.

Boland, R.J. and Tenkasi, R.V. (1995) 'Perspective making and perspective taking in communities of knowing', Organization Science, Vol. 6, No. 4, pp.350-372.

Boyer, P. and Ramble, C. (2001) 'Cognitive templates for religious concepts: cross-cultural evidence for recall of counter-intuitive representations', Cognitive Science, Vol. 25, No. 4, pp.535-564.

Burt, J., James, A. and Price, L. (2018) 'A peaceful revenge', Journal of Critical Realism, Vol. 17, No. 5, pp.492-513.

Chai, S. (2017) 'Near misses in the breakthrough discovery process', Organization Science, Vol. 28, No. 3, pp.411-428.

Cheng, Y-C. (2011) 'Why and how to globalize traditional Chinese medicine', Journal of Traditional and Complementary Medicine, Vol. 1, No. 1, pp.1-4.

Christianson, M.K. (2019) 'More and less effective updating: the role of trajectory management in making sense again', Administrative Science Quarterly, Vol. 64, No. 1, pp.45-86.

D'Andrade, R.G. (1981) 'The cultural part of cognition', Cognitive Science, Vol. 5, No. 3, pp.179-195.

Dane, E. (2018) 'Where is my mind? Theorizing mind wandering and its performance-related consequences in organizations', Academy of Management Review, Vol. 43, No. 2, pp.179-197.

Dutton, J.E. and Dukerich, J.M. (1991) 'Keeping an eye on the mirror. Image and identity in organizational adaptation', Academy of Management Journal, Vol. 34, No. 3, pp.517-554.

Elsbach, K.D., Barr, P.S. and Hargadon, A.B. (2005) 'Identifying situated cognition in organizations', Organization Science, Vol. 16, No. 4, pp.327-451.

Fay, B. (1990) 'Critical realism?', Journal for the Theory of Social Behaviour, Vol. 20, No. 1, pp.33-41.

Fay, N., Walker, B., Swoboda, N. and Garrod, S. (2018) 'How to create shared symbols', Cognitive Science, Vol. 42, No. S1, pp.241-269.

Franke, R.H., Hofstede, G. and Bond, M.H. (1991) 'Cultural roots of economic performance: a research note', Strategic Management Journal, Vol. 12, No. S1, pp.165-173.

Gallant, V., Vachon, J. and Siu, W. (2017) 'Tuberculosis drug resistance in Canada: 2006-2016', Releve des maladies transmissibles au Canada, Vol. 43, No. 11, pp.236-241.

Galván, J.A.G. (1997) 'El estado pluricultural de derecho: Los principios y los derechos indígenas constitucionales', Boletín Mexicano de Derecho Comparado, No. 88, pp.169-190.

Gao, C., Zuzul, T., Jones, G. and Khanna, T. (2017) 'Overcoming institutional voids: a reputation-based view of long-run survival', Strategic Management Journal, Vol. 38, No. 11, pp.2147-2167.

Gavetti, G. (2005) 'Cognition and hierarchy: rethinking the microfoundations of capabilities' development', Organization Science, Vol. 16, No. 6, pp.599-617.

Gavetti, G. and Levinthal, D. (2000) 'Looking forward and looking backward: cognitive and experiential search', Administrative Science Quarterly, Vol. 45, No. 1, pp.113-137.

Gavetti, G. and Warglien, M. (2015) 'A model of collective interpretation', Organization Science, Vol. 26, No. 5, pp.1263-1283.

Gelfand, M.J., Raver, J.L., Nishii, L., Leslie, L.M., Lun, J., Beng, C.L., Duan, L., Almaliach, A., Soon, A., Arnadottir, J., Aycan, Z., Boehnke, K., Boski, P., Cabecinhas, R., Chan, D., Chhokar, J., D'Amato, A., Ferret, M., Fischlmayr, I.C. and Fischer, R. (2011) 'Differences between tight and loose cultures: a 33-nation study', Science, Vol. 332, No. 6033, pp.1100-1104. 
Gioia, D.A., Price, K.N., Hamilton, A.L. and Thomas, J.B. (2010) 'Forging an identity: an insider-outsider study of processes involved in the formation of organizational identity', Administrative Science Quarterly, Vol. 55, No. 1, pp.1-46.

Giorgi, S. (2017) 'The mind and heart of resonance: the role of cognition and emotions in frame effectiveness', Journal of Management Studies, Vol. 54, No. 5, pp.711-738.

Granero, A.G., Mesa, A.F., Justin, J.P.J. and Jurado, J.V. (2017) 'Top management team diversity and ambidexterity: The contingent role of shared responsibility and CEO cognitive trust', Long Range Planning [online] https://doi.org/10.1016/j.lrp.2017.11.001.

Grewatsch, S. and Kleindienst, I. (2017) 'How organizational cognitive frames affect organizational capabilities: the context of corporate sustainability', Long Range Planning [online] http://dx.doi.org/10.1016/j.lrp.2017.03.004.

Güss, C.D., Tuason, M.T. and Gerhard, C. (2010) 'Cross-national comparisons of complex problem-solving strategies in two microworlds', Cognitive Science, Vol. 34, No. 3, pp.489-520.

Harré, R. (2009) 'Saving critical realism', Journal for the Theory of Social Behaviour, Vol. 39, No. 2, pp.129-143.

Helfat, C.E. and Peteraf, M.A. (2015) 'Managerial cognitive capabilities and the microfoundations of dynamic capabilities', Strategic Management Journal, Vol. 36, No. 6, pp.831-850.

Henriques, S.T. and Borowiecki, K.J. (2017) 'The drivers of long-run CO2 emissions in Europe, North America and Japan since 1800', Energy Policy, Vol. 101, pp.537-549.

Hockey, N. (2010) 'Engaging postcolonialism', Journal of Critical Realism, Vol. 9, No. 3, pp.353-383.

Hofstede, G. (2010) Cultures and Organizations: Software of the Mind: Intercultural Cooperation and its Importance for Survival, McGraw-Hill, New York, NY.

Hong, Y-Y. and Chiu, C-Y. (2001) 'Toward a paradigm shift: from cross-cultural differences in social cognition to social-cognitive mediation of culture differences', Social Cognition, Vol. 19, No. 3, pp.181-196.

Hong, Y-Y., Morris, M.W., Chiu, C-Y. and Benet-Martínez, V. (2000) 'Multicultural minds: a dynamic constructivist approach to culture and cognition', American Psychologist, Vol. 55, No. 7, pp.709-720.

Huanan, G. (2017) 'Senses and cognition in early Chinese thought', Social Sciences in China, Vol. 38, No. 4, pp.28-44.

Hwang, K-K. (2015) 'Cultural system vs. pan-cultural dimensions', Journal for the Theory of Social Behaviour, Vol. 45, No. 1, pp.2-25.

Irwin, J., Lahneman, B. and Parmigiani, A. (2017) 'Nested identities as cognitive drivers of strategy', Strategic Management Journal, Vol. 39, No. 2, pp.269-294.

Jalonen, K., Schildt, H. and Vaara, E. (2018) 'Strategic concepts as micro-level tools in strategic sensemaking', Strategic Management Journal, Vol. 39, No. 10, pp.2794-2826.

Journé, B. and Raulet-Croset, N. (2012) 'La décision comme activité managériale située', Revue Française de Gestion, Vol. 38, No. 225, pp.109-128.

Kaplan, S. (2008) 'Cognition, capabilities, and incentives: assessing firm response to the fiber-optic revolution', Academy of Management Journal, Vol. 51, No. 4, pp.672-695.

Kiesler, S. and Sproull, L. (1982) 'Managerial response to changing environments: perspectives on problem sensing from social cognition', Administrative Science Quarterly, Vol. 27, No. 4, pp.548-570.

Klein, S.M. (1973) 'Geographical impact on the cognitions of new factory workers: a comparative factor analysis', Academy of Management Journal, Vol. 16, No. 3, pp.442-453.

Krackhardt, D. (1990) 'Assessing the political landscape: structure, cognition, and power in organizations’, Administrative Science Quarterly, Vol. 35, No. 2, pp.342-369. 
Laamanen, T., Maula, M., Kajanto, M. and Kunnas, P. (2017) 'The role of cognitive load in effective strategic issue management', Long Range Planning [online] http://dx.doi.org/ 10.1016/j.lrp.2017.03.001.

Leslie, L.M., King, E.B. and Clair, J.A. (2019) 'Work-life ideologies: the contextual basis and consequences of beliefs about work and life', Academy of Management Review, Vol. 44, No. 1, pp.72-98.

Li, C., Brodbeck, F.C., Shenkar, O. and Ponzi, L.J. (2017) 'Embracing the foreign: cultural attractiveness and international strategy', Strategic Management Journal, Vol. 38, No. 4, pp.950-971.

Liang, H., Marquis, C., Renneboog, L. and Sun, S.L. (2018) 'Future-time framing: the effect of language on corporate future orientation', Organization Science, Vol. 29, No. 6, pp.1093-1111.

Lubinski, C. and Wadhwani, R.D. (2019) 'Geopolitical jockeying: economic nationalism and multinational strategy in historical perspective', Strategic Management Journal [online] https://doi.org/10.1002/smj.3022.

Lücke, G., Kostova, T. and Roth, K. (2014) 'Multiculturalism from a cognitive perspective: patterns and implications', Journal of International Business Studies, Vol. 45, No. 2, pp.169-190.

Maitland, E. and Sammartino, A. (2015) 'Managerial cognition and internationalization', Journal of International Business Studies, Vol. 46, No. 7, pp.733-760.

Marchal, K. (2017) 'Agency, culture, modernity: towards a new understanding of Confucian practical reasoning', Journal of Chinese Philosophy, Vol. 44, Nos. 3-4, pp.230-250.

Masuda, T. and Nisbett, R.E. (2006) 'Culture and change blindness', Cognitive Science, Vol. 30, No. 2, pp.381-399.

Menéndez, E.L. (2018) Colonialismo, neocolonialismo y racismo: El papel de la ideología y de la ciencia en las estrategias de control y dominación, Universidad Nacional Autónoma de México, México, DF.

Meyer, K.E., Estrin, S., Bhaumik, S.K. and Peng, M.W. (2009) 'Institutions, resources, and entry strategies in emerging economies', Strategic Management Journal, Vol. 30, No. 1, pp.61-80.

Mezias, J.M., Grinyer, P. and Guth, W.D. (2001) 'Changing collective cognition: a process model for strategic change', Long Range Planning, Vol. 34, No. 1, pp.71-95.

Michel, A.A. (2007) 'A distributed cognition perspective on newcomers' change processes: the management of cognitive uncertainty in two investment banks', Administrative Science Quarterly, Vol. 52, No. 4, pp.507-557.

Mitchell, R.K., Smith, B., Seawright, K.W. and Morse, E.A. (2000) 'Cross-cultural cognitions and the venture creation decision', Academy of Management Journal, Vol. 43, No. 5, pp.974-993.

Muggleton, N.G. and Banissy, M.J. (2014) 'Culture and cognition', Cognitive Neuroscience, Vol. 5, No. 1, pp.1-2.

Negro, G. and Longhofer, W. (2018) 'World society, legal formalism, and execution of legal procedures', Social Forces, Vol. 97, No. 2, pp.649-674.

Norenzayan, A., Smith, E.E., Kim, B.J. and Nisbett, R.E. (2002) 'Cultural preferences for formal versus intuitive reasoning', Cognitive Science, Vol. 26, No. 5, pp.653-684.

Núñez, R.E. and Cornejo, C. (2012) 'Facing the sunrise: cultural worldview underlying intrinsic-based encoding of absolute frames of reference in Aymara', Cognitive Science, Vol. 36, No. 6, pp.965-991.

Oliver, N., Calvard, T. and Potočnik, K. (2017) 'Cognition, technology, and organizational limits: lessons from the Air France 447 disaster’, Organization Science, Vol. 28, No. 4, pp.597-780.

Oyserman, D. (2011) 'Culture as situated cognition: cultural mindsets, cultural fluency, and meaning making', European Review of Social Psychology, Vol. 22, No. 1, pp.164-214.

Peterson, M.F. and Barreto, T.S. (2018) 'Interpreting societal culture value dimensions', Journal of International Business Studies, Vol. 49, No. 9, pp.1190-1207. 
Petriglieri, G., Ashford, S.J. and Wrzesniewski, A. (2019) 'Agony and ecstasy in the gig economy: cultivating holding environments for precarious and personalized work identities', Administrative Science Quarterly, Vol. 64, No. 1, pp.124-170.

Pinder, C.C. and Bourgeois, V.W. (1982) 'Controlling tropes in administrative science', Administrative Science Quarterly, Vol. 27, No. 4, pp.641-652.

Porac, J.F., Thomas, H. and Baden-Fuller, C. (1989) 'Competitive groups as cognitive communities: the case of Scottish knitwear manufacturers', Journal of Management Studies, Vol. 26, No. 4, pp.397-416.

Pratten, S. (2013) 'Critical realism and the process account of emergence', Journal for the Theory of Social Behaviour, Vol. 43, No. 3, pp.251-279.

Putranto, N.A.R., Nuraeni, S., Gustomo, A. and Ghazali, A. (2018) 'The relationship between cultural intelligence, emotional intelligence, and student performance', International Journal of Business, Vol. 23, No. 1, pp.17-25.

Raffaelli, R., Glynn, M.A. and Tushman, M. (2019) 'Frame flexibility: the role of cognitive and emotional framing in innovation adoption by incumbent firms', Strategic Management Journal [online] https://doi.org/10.1002/smj.3011.

Roberts, J.M. (2014) 'Critical realism, dialectics, and qualitative research methods', Journal for the Theory of Social Behaviour, Vol. 44, No. 1, pp.1-23.

Ronen, S. and Shenkar, O. (2013) 'Mapping world cultures: cluster formation, sources and implications', Journal of International Business Studies, Vol. 44, No. 9, pp.867-897.

Ruddiman, W.F. (2003) 'The anthropogenic greenhouse era began thousands of years ago', Climatic Change, Vol. 61, No. 3, pp.261-293.

Salvato, C. and Vassolo, R. (2017) 'The sources of dynamism in dynamic capabilities', Strategic Management Journal, doi: 10.1002/smj.2703.

Sen, S. and Chakraborty, R. (2017) 'Revival, modernization and integration of Indian traditional herbal medicine in clinical practice: importance, challenges and future', Journal of Traditional and Complementary Medicine, Vol. 7, No. 2, pp.234-244.

Senzaki, S., Masuda, T. and Ishii, K. (2014) 'When is perception top-down and when is it not? Culture, narrative, and attention', Cognitive Science, Vol. 38, No. 7, pp.1493-1506.

Shin, D., Hasse, V.C. and Schotter, A.P.J. (2017) 'Multinational enterprises within cultural space and place: integrating cultural distance and tightness-looseness', Academy of Management Journal, Vol. 60, No. 3, pp.904-921.

Simon, H.A. (1987) 'Making management decisions: the role of intuition and emotion', Academy of Management Executive, Vol. 1, No. 1, pp.57-64.

Smircich, L. (1983)' Concepts of culture and organizational analysis', Administrative Science Quarterly, Vol. 28, No. 3, pp.339-358.

Steers, R.M., Sanchez-Runde, C.J. and Nardon, L. (2012) 'Culture, cognition, and managerial leadership', Asia Pacific Business Review, Vol. 18, No. 3, pp.425-439.

Strickland, B. (2017) 'Language reflects 'core' cognition: a new theory about the origin of cross-linguistic regularities', Cognitive Science, Vol. 41, No. 1, pp.70-101.

Strohminger, N. and Nichols, S. (2014) 'The essential moral self', Cognition, Vol. 131, No. 1, pp.159-171.

Sullivan, D. (1998) 'Cognitive tendencies in international business research: implications of a 'narrow vision', Journal of International Business Studies, Vol. 29, No. 4, pp.837-862.

Tcheang, L. (2014) 'Culture and math', Cognitive Neuroscience, Vol. 5, No. 1, pp.54-65.

Teece, D.J. (2007) 'Explicating dynamic capabilities: the nature and microfoundations of (sustainable) enterprise performance', Strategic Management Journal, Vol. 28, No. 13, pp.1319-1350.

Tenzer, H., Pudelko, M. and Harzing, A-W. (2014) 'The impact of language barriers on trust formation in multinational teams', Journal of International Business Studies, Vol. 45, No. 5, pp.508-535. 
Thoroughgood, C.N., Sawyer, K.B. and Webster, J.R. (2019) 'Finding calm in the storm: a daily investigation of how trait mindfulness buffers against paranoid cognition and emotional exhaustion following perceived discrimination at work', Organizational Behavior and Human Decision Processes [online] https://doi.org/10.1016/j.obhdp.2019.02.004.

Tripsas, M. and Gavetti, G. (2000) 'Capabilities, cognition, and inertia: evidence from digital imaging', Strategic Management Journal, Vol. 21, Nos. 10-11, pp.1147-1161.

Ueda, Y., Chen, L., Kopecky, J., Cramer, E.S., Rensink, R.A., Meyer, D.E., Kitayama, S. and Saiki, J. (2017) 'Cultural differences in visual search for geometric figures', Cognitive Science doi:10.1111/cogs. 12490 .

Umla-Runge, K., Fu, X., Wang, L. and Zimmer, H.D. (2014) 'Culture-specific familiarity equally mediates action representations across cultures', Cognitive Neuroscience, Vol. 5, No. 1, pp.26-35.

van Hoorebeke, D. (2008) 'L'émotion et la prise de décision', Revue Française de Gestion, Vol. 44, No. 182, pp.33-44.

van Knippenberg, D., van Ginkel, W.P. and Homan, A.C. (2013) 'Diversity mindsets and the performance of diverse teams', Organizational Behavior and Human Decision Processes, Vol. 121, No. 2, pp.183-193.

Volk, S., Köhler, T. and Pudelko, M. (2014) 'Brain drain: the cognitive neuroscience of foreign language processing in multinational corporations', Journal of International Business Studies, Vol. 45, No. 7, pp.862-885.

Vora, D., Martin, L., Fitzsimmons, S.R., Pekerti, A.A., Lakshman, C. and Raheem, S. (2018) 'Multiculturalism within individuals: a review, critique, and agenda for future research', Journal of International Business Studies [online] https://doi.org/ 10.1057/s41267-0180191-3.

Voyer, J.J. (1994) 'Coercive organizational politics and organizational outcomes: An interpretive study', Organization Science, Vol. 5, No. 1, pp.72-85.

Vuori, T.O. and Huy, Q.N. (2016) 'Distributed attention and shared emotions in the innovation process: How Nokia lost the smartphone battle', Administrative Science Quarterly, Vol. 61, No. 1, pp.9-51.

Wade, S. and Kidd, C. (2018) 'Cross-cultural differences in the influence of peers on exploration during play', Cognitive Science, Vol. 42, No. 8, pp.3050-3070.

Wang, J., Cheng, G.H-L., Chen, T. and Leung, K. (2019) 'Team creativity/innovation in culturally diverse teams: a meta-analysis', Journal of Organizational Behavior [online] https://doi.org/ 10.1002/job.2362.

Willard, A.K. and McNamara, R.A. (2019) 'The minds of god(s) and humans: differences in mind perception in Fiji and North America', Cognitive Science [online] https://doi.org/10.1111/ cogs. 12703.

Wong, K.F.E. and Kwong, J.Y.Y. (2018) 'Resolving the judgment and decision-making paradox between adaptive learning and escalation of commitment', Management Science, Vol. 64, No. 4, pp.1911-1925.

Zhang, B., Galbraith, N., Yama, H., Wang, L. and Manktelow, K.I. (2015) 'Dialectical thinking: a cross-cultural study of Japanese, Chinese, and British students', Journal of Cognitive Psychology, Vol. 27, No. 6, pp.771-779.

Zunino, D., Suarez, F.F. and Grodal, S. (2019) 'Familiarity, creativity, and the adoption of category labels in technology industries', Organization Science [online] https://doi.org/10.1287/ orsc.2018.1238. 